\title{
The Development of Teacher Quality Assurance Model After Certification
}

\author{
Sakinah Ubudiyah Siregar \\ Faculty of Pascasarjana \\ Doctoral Program of Education Management \\ State University of Medan, \\ Medan, Indonesia \\ Corresponding email: sakinah.ubudiyah@yahoo.com
}

\begin{abstract}
Teacher certification is the provision of educator certificates to teachers who have met certain requirements, such as having academic qualifications, competence, physical and spiritual health, and having the ability to realize national education goals. The purpose of this study is the perception of teachers who have not participated in the certification program for certification of educators through the portfolio pathway, and the design of the teacher quality assurance model after certification. This kind of research used Research and Development for two years. Data Collection was conducted by distributing questionnaires, documentation and interview. The data were analyzed quantitively and qualitatively. The result showed that the teacher certification program that has been implemented to date has given positive impact for teacher performance improvement and the model design of quality assurance system of teacher performance after certification includes components of main task performance, additional task performance and professional development performance. This means that the completion is conducted by socialization and trial test. The result of socialization and trial test will be the materials for revision and model improvement as tobe feasible or not the dissemination for wider class is conducted.
\end{abstract}

Keywords- Certification; Teacher Performance

\section{INTRODUCTION}

Teacher certification is the provision of educator certificates to teachers who have met certain requirements, such as having academic qualifications, competence, physical and spiritual health, and having the ability to realize national education goals, which are valued withdecent welfare improvement (Masnur, 2007: 2). That teachers must have academic qualifications, competence, certification of educators, physically and mentally healthy and have the ability to realize national education goals. Then a competency test process designed to reveal the mastery of one's competence as a basis for educator certification (according to Mulyasa
"2007:34). The teacher must go through a bachelor's degree or diploma.

Teacher certification objectives: Protection of professional and personnel education, protecting people from incompetent practices, thus damaging the image of teachers and education workers, Assistance and protection of educators, by providing signs and tools to make choices from eligible candidates, community perception of the teaching profession and education workers, as well as providing solutions to improve the quality of education and teachers.

Successful institutions in implementing teacher certification programs will produce professional teachers to improve the quality of teacher performance. For this reason the teacher's performance can be improved by obtaining maximum results in carrying out tasks and work targets or performance criteria put forward by experts (Szilagyi\& Wallace, 1983: 360 tolovic \& Keeps, 1992: 4: Cascio, 1992: 267: Hersey\& Blanchard, 1996: 406). To get quality learning processes and good results, it requires maximum teacher performance. For this reason, the teacher can show high performance that has knowledge and mastery of the material that will be taught to students so that learning can be effective and efficient and has a commitment to carry out tasks as a teacher.

Teacher performance is a professional profession in which he is required to do everything possible to carry out his profession as best as possible. As a professional, the task of the teacher as an educator, and trainer should be able to impact on their students. In this case, the teacher should be able to continuously improve its performance as a capital for the success of an education.

Based on the definition above, performance is the result or level of success of a person overall during a certain period in carrying out a task compared to various possibilities, such as work standards, targets or criteria that have been determined in advance and mutually agreed.

Teacher's teaching hours are at least 24 hours in accordance with article 35 paragraphs 2 of Law number 14 of 2005 concerning on teachers and lecturers. Some teachers find it 
difficult to fulfill the mandatory hours of teaching, especially teachers in private schools because private teachers only have 12-18 teaching hours per a week.

There are problems that arise due to the lack of management of the teacher included in terms of good performance management. The challenge that we can see is the teacher education system that is less qualified in meeting the workload, there is a lack of clarity in the management of the teacher's task which ensures education can run well, teachers do not have clear teaching hours in carrying out their daily tasks, and the guarantee of the quality of the implementation of teacher education is not representative.

This shows the importance of developing a good model by preparing certified teachers. Problems in this study: What is the impact of teacher certification on improving teacher performance? How is the design of the teacher quality assurance model after certification?

\section{METHOD}

This research used Research and Development for 2 years. Data collection is done by distributing questionnaires, documentation, and interviews. Data were analyzed with quantitative and qualitative approaches. the stages of this research were as follows: Analysis of problems and needs, planning, development, implementation, control, and socialization. The first time began with an activity to survey the regulations and guidelines for the implementation of teacher certification in schools. Then visiting the education quality assurance agency, the Education Office, the district / city education office, school and discuss with teachers, principals, practitioners and students. The two results of the activities in the first stage were studies to plan the teacher performance quality assurance model after certification. The data sources obtained for vocational secondary schools were 9 principals and 152 teachers. The first stage began by reviewing various literatures, surveying regulations and guidelines for the implementation of teacher certification and its implementation in schools. Then visit the education quality assurance agency, the Education Office, the district / city education office, schools as well as discussions with teachers and students. Then the second stage is carried out, the results of the first stage are materials for planning the preparation model and quality assurance of teacher performance. Then the next stage was workshop which was designing a model for preparing certification and quality assurance of teacher performance after certification. The development of the model began with the identification of implementation and problems in preparing certification and quality assurance in vocational high schools. The next stage was formulating the device model. Then the device was validated by experts in accordance with the field under study. After the device was prepared, then proceed to the model test. The trial was planned in 2 pilot vocational high schools with different types. The results of this trial were then reflected to make further action plans.
The data needed for this study were the teachers' perceptions of the certification program for teachers who had not participated in certification activities, the impact of certification for teachers who had passed certification, and a quality assurance model to monitor teacher performance after certification.

\section{DISCUSSION}

The findings of the research were: there was an increase that supports teacher performance, teacher certification programs had an effective impact in improving teacher competency or performance, the side impact of certification was the emergence of social jealousy from teachers who had not been certified, The teacher understands the importance of certification for teachers as an effort to improve the quality of education in Indonesia, in addition to increasing the level of teacher welfare, Although there are many administrative burdens carried out by principals, school climate and culture fully support efforts to improve post certification performance, post certification teacher performance quality assurance models were important to design, and components of teacher performance could be seen from the performance in carrying out basic tasks, performance in carrying out tasks outside the main tasks, and performance in developing professionalism.

Teachers understand the importance of certification as an effort to improve the quality and welfare degree of teachers. From the questions that must be answered regarding the understanding of certification, most teachers gave a positive assessment in the form of consent to the purpose of the question and to the impact of certification on performance improvement which was outlined in 25 questions

The variable of teacher performance after certification could be described as follows, that $80 \%$ of respondents answered that certification was effective in improving teacher competence or performance. The remaining $20 \%$ of teachers answered that it did not or had not been effective in improving teacher competency or performance, The teacher considers that post-certification performance improvement was more influenced by the nature of each individual. Certification was only administrative, even teachers saw cheating in various ways to obtain certification.

Guidence in terms of improving post-certification performance so far had been carried out by principals and supervisors from the district education and sports services. It was still considered by some teachers to be ineffective because there were many shortcomings. Facilities and infrastructure, training, workshops, industry training were some of what teachers need in an effort to improve post-certification performance in addition to allowances could be disbursed regularly.

All teachers as respondents in this study stated the importance of ensuring the quality of teacher performance after certification. The proposed guarantee measures or patterns 
include competency-based training, teacher administration preparation,and guidance on learning strategies, periodic monitoring, and training in industry. Performance in carrying out basic tasks included teaching assignments (planning learning, implementing learning, managing classes, and assessing learning outcomes), educating, training, guiding, administrative tasks, school development, additional assignments and other non-academic tasks that support the main tasks. While the development of professionalism concerning the aspects of self-development and the profession included: education and training, research and professional development work.

\section{CONCLUSION}

The teacher professional certification program that had been implemented had a positive impact on teacher performance;Teachers' perception of professional certification programs to improve teacher performance was positive, the design of the post-certification teacher performance quality assurance system model included the components of the main task performance, additional task performance, and professional development performance. The design of the model in this study had received input from teacher group discussion activities and needed to be refined by socializing the trial as a revision material for the model improvement so that it was feasible to disseminate to a wider group.

\section{REFERENCES}

[1] Enco Mulyasa, "Teacher Competency and Certification Standards", Bandung, Rosdakarya, 2007, pp 34

[2] Masnur Muslich, "Teacher Certification Towards Educator Professionalism", Jakarta, BumiAksara, 2007, p 2

[3] Szilagyi, A. D. \& Wallace, J. M. Jr. , "Organizational behaviour and performance", USA: Scott, Foresman \& Co. 1983, p 56 